\title{
THE ICONOGRAPHY OF SHEEP IN THE VISUAL CULTURE OF THE PAGAN PARADISE: AN EXAMPLE OF LATE ANTIQUITY IN ANTIOCH
}

\author{
J T Garcia (Autonomous University of Madrid)
}

\begin{abstract}
The presence of certain animals in the iconographic programs of Late Antiquity is closely linked to different conditions. In our particular case, we propose to analyze a mosaic of the Allard Pierson Museum in Amsterdam: a fat-tailed sheep (c. AD 475) from an early Christian Church near Antioch. Greek culture was strongly rooted in Antioch, and Roman visual culture had a strong influence on the artistic currents that reached the oriental city. These geographical and cultural factors, in addition to the iconographic program of Paradise, form a context of analysis that will allow us to identify how the presence of the sheep has evolved in the visual culture of Antiquity.
\end{abstract}

Keywords: sheep; Paradise; Antioch; Late Antiquity; mosaic

\section{Introduction}

Antioch floor mosaics have served as a useful indicator of the tastes of iconographic and stylistic Roman and early Byzantine periods due to its nearly 500 years of uninterrupted production. The diversity of the decorations on the mosaic floors, including depictions of humans, animals, and plant elements, show the diversity in the taste of the artist. ${ }^{1}$ The discoveries of mosaic floors from Roman Syria come from Antioch, Seleucia, and Daphne. A number of approaches have characterized the study of mosaics in the eastern provinces of Rome and Byzantium. Levi, one of the best experts on the subject of the Roman mosaics of Antioch, studied the development and diffusion of style in the villas of Antioch, and considered the possible symbolic content of this iconography. ${ }^{2} \mathrm{He}$ suggested,

1 Lassus 1936:33-42. The emergence of animal themes in Romano-Syrian mosaics in the $5^{\text {th }}$ century AD and later is discussed in Dunbabin 1999:179-186.

2 Much of Levi's work in connection with the Antioch mosaics addressed this question of foreign influence, and he reached the conclusion that the change could best be explained, not by any influx from the Orient, but as the product of a logical evolution within the ambient of Greco-Roman culture. Cf. Levi 1947. Levi's method gave an exhaustive description of the stylistic evolution of the individual components of the pavement designs, for instance, geometric and floral ornaments, figures and animals, citing parallels and precedents from all parts of the Empire. In this way, the examples at Antioch become illustrations of a larger evolution, and a picture of harmony within the Greco-Roman world inevitably emerges. A more penetrating analysis of the Antioch 
for instance, that scenes that have a mythological theme, such as hunting scenes, tended to lose their mythological aspect during Roman times and have gained symbolic value by becoming a hunting genre. Some of the best-preserved mosaics come from Christian religious environments, and many of them are characterized by a geometric style. ${ }^{3}$ The cataloguing of the mosaics of Israel up to 1935 by M Avi-Yonah, was extended up to 1975 by R Ovadiah and A Ovadiah. ${ }^{4}$

Especially interesting for our subject matter is a mosaic depicting a fattailed sheep (c. 475 AD) from an early Christian Church near Antioch (Fig. 1). Fat-tailed sheep like these belong to a common type of domestic sheep and are renowned for their distinctive large tails and hindquarters. Fat-tailed sheep breeds comprise approximately $25 \%$ of the world sheep population. The Awassi sheep is the most numerous and widespread breed of sheep found in south-west Asia. It is also the dominant type found in Iraq, the most important sheep in the Syrian Arab Republic and the only indigenous breed of sheep found in Lebanon, Jordan and Israel. Depictions of this animal, often featured in company of other domestic animals such as pigeons, ducks, pheasants, or horses, occurred commonly in mosaics throughout the Roman world and represented aspects of an idyllic pastoral life. $^{5}$

The hunting scene as depicted on Early Byzantine ecclesiastical floors appears to have perpetuated symbolism stemming from the Roman period. In essence, hunting scenes in churches were viewed as an expression of the patron's prestige and virtus. In the pastoral mosaics, the treatment of space is more abstract, and the arrangement of landscape elements in superimposed registers, rather than receding planes, introduced a system that became a feature of mediaeval art. The most remarkable aspect of the mosaic that I propose to analyze is the coexistence of a work in a Christian context with a Roman aesthetic.

pavements from this point of view is to be found in Morey 1938; some of the arrangements have been discussed by Stillwell 1961:45 ff.

3 Other Syrian geometric mosaics from the second half of the $4^{\text {th }}$ century or early $5^{\text {th }}$ century, such as the Church of the Inscription at Has (388-389), cf. Donceel-Voûte 1988:117-119, the Apamea Synagogue, and Deir Charqi are dated through inscriptions, contextual evidence and comparisons in style and motif. Cf. Balty 1984:441.

4 In both cases, the classification of iconography represented a somewhat deconstructive approach since these did not take into consideration an adequate account of broader issues, such as the diffusion of style or symbolism, Merrony 1998:441. The most recent contributions to the subject can be found in Madden 2014.

5 Belis 2016, presents panels with animals in the J Paul Getty Museum that may have come from a church in Emesa and are dated from AD 400-600. These fragmentary mosaics represent various animals - bulls, a lion, a horse, a rabbit, a donkey, a stag, an eagle, peacocks, and other birds. The author notes that depictions of animals were typical features of church mosaics in the region. 
Therefore, the aim of this article is to reconstruct the artistic context of the mosaics at Antioch. In addition, I will review the iconographic motif of animals from pastoral life to explain how Roman mosaics created a visual culture with this particular type of lifestyle.

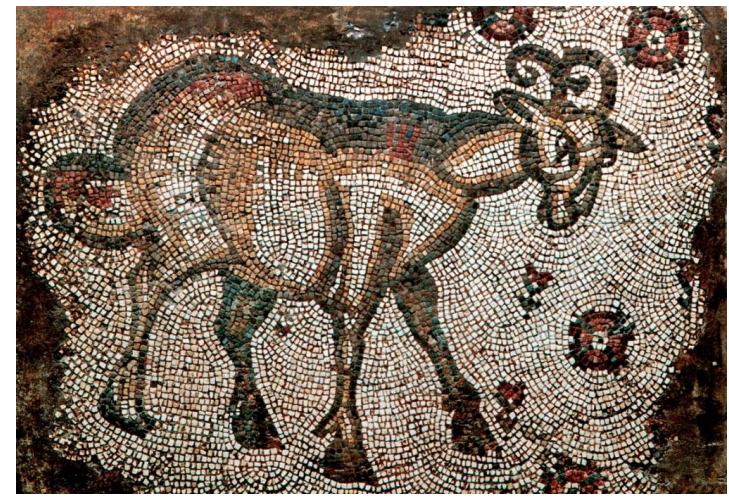

Fig. 1: Fragment of mosaic with a sheep, Syria (Antioch), AD 450-500. Allard Pierson Museum (APM09850).

\section{Sheep in ancient material cultures}

The presence of sheep in ancient cultures is attested from various points of view. Humans took a crucial step towards modern civilization when they began a process of animal domestication. By approximately $10000 \mathrm{BC}$, the residents of the eastern Mediterranean started to domesticate animals. ${ }^{6}$ They began to gather herds of goats and sheep, not only to provide meat, but also wool and milk.

It is very difficult at present to ascertain the origin of the domestication of sheep. For many ancient cultures sheep symbolized security, harmony, and abundance. Most species of wild sheep are found in Asia, and it is conceivable that some species may have spread from the highlands of Central Asia to other parts of their habitat. ${ }^{7}$ Sheep also had symbolic significance in the cultural traditions and

6 Zeuner 1963:78-98, emphasizes how the Greeks, Romans, and other cultures set significant store in the sacrifice of animals in order to placate the gods and no doubt sheep where included amongst the animals deemed suitable as sacrificial offerings. The most significant contribution to this subject is the recent publication edited by Campbell 2014.

7 The study of ovicaprid bone assemblages from north-eastern Iraq and south-eastern Anatolia, from around $10000 \mathrm{BC}$, suggests early human attempts to manipulate sheep and goat herd demographics by hunting two- to three-year-old males. Kristensen 1971:152-163; Reeding 2005:41-48. 
religions of the ancient Mediterranean, especially those emanating from JudeoChristian beliefs. ${ }^{8}$

Sheep breeding quickly spread throughout Europe - the fat from fat-tailed sheep, for instance, was used in foods, candies, and soaps. ${ }^{9}$ The earliest record of this sheep variety is found in ancient Uruk (3000 BC) and Ur (2400 BC) on stone vessels and mosaics. An early reference is found in the Bible (Leviticus 3:9), where a sacrificial offering is described which includes the tail fat of sheep. The Awassi sheep breed is common in most of the Middle East Countries including Saudi Arabia, Jordan, Iraq, Syria, Lebanon, Israel and Palestine (Fig. 2). In biblical context the first mention of sheep is in terms of its importance in sacrificial offering (Genesis 4:2), and as an important article of food (Samuel 25:18). Sheep and lambs are sometimes used to pay tribute (Kings 3:4). It is very striking to notice the huge number of sheep reared in Palestine in biblical times. ${ }^{10}$

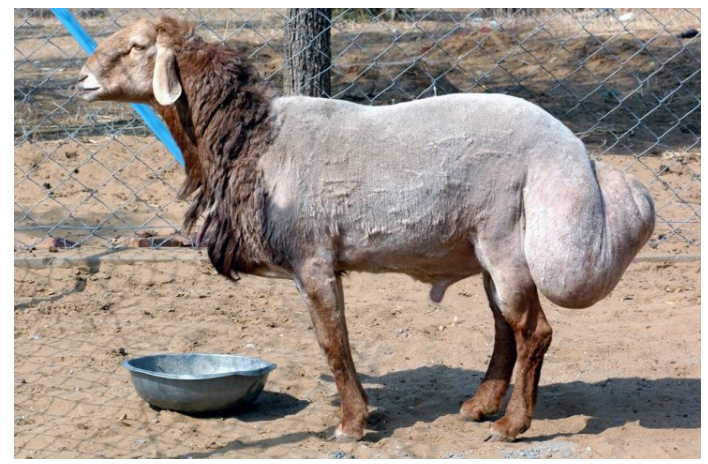

Fig. 2: Awassi sheep, ICAR. The Central Sheep and Wool Research Institute.

8 How human animals and non-human animals relate to each other depends on the moral, material and technological developments in a particular human society. It further depends on how the distinctions between humans and animals are drawn and which type of animal species we are talking about. The cultural value of animals is strongly influenced by their usefulness to man, whether they are conceived of as useful, destructive or neither. $C f$. Glihus 2006:12. Howe 2008, analyzes the practice of animal husbandry in relation to sociopolitical and economic causes that informed and shaped this practice in ancient Greece during the Archaic, Classical, and early Hellenistic periods.

9 Lev Tov \& McGeough 2006:85-90, - note that in terms of species abundance the remains of three domestic animals, sheep (Ovis aries), goats (Capra hircus), and cattle (Bos taurus) have been found in Palestine from the Bronze Age.

10 As Sandwell 2007:46 notes, sheep is the most-mentioned animal in the Bible. They were domesticated about $5000 \mathrm{BC}$ from wild species that since became extinct. The Bible says that Abel, son of Adam and Eve, was a 'breeder of sheep' (Genesis 4:3). 
Sheep husbandry quickly became an important factor in the Roman economy. ${ }^{11}$ Sheep were used for a range of products; meat, milk and wool. However, this breed was raised primarily for milk. The Roman diet, originally marked by a pastoral economy type, attaches great importance to dairy products, especially milk and cheese. Milk, as well as its derivatives, is one of the oldest products of humanity. According to Varro (Rust. 2.11.1) milk is a most nutritious food, 'sheep's milk and goat then, are all the more nutritious liquid foods'. Mare's milk had a mainly cosmetic utility, providing smoothness to the skin, so that, again according to Pliny, some women washed their faces seven times a day with donkey milk to have smooth skin (HN 28, 50). The Empress Poppea bathed in asses' milk daily to maintain soft white skin and had herds of mares moved close to her. Vergil explains that milk collected in the morning was used to make cheese, while milk collected during the evening was taken to the city to sell (Geor. 3.400).

Exploitation of animals on their farms was usual practice for the Roman Empire, and a fundamental part of their material culture. In general terms, the kind of society contributes to determine the view of animals; an agricultural society will have other prospects than a society of hunters and gatherers. ${ }^{12}$ Some people, such as farmers, hunters and fishermen depend on animals for their livelihood. In small farms and villas, people lived closer to the animal population than they did in Rome. The relationship between humans and sheep, for example, will always be different from the way human beings relate to wild animals for other purposes.

In the Graeco-Roman culture, simple rural life was considered morally superior to life in the cities. The cultural value of animals is strongly influenced by their usefulness to humans, whether they are conceived of as useful, destructive or neither. In Roman law, animals and slaves were sometimes treated similar according to the Lex Aquilia, for instance, it is stated that 'If anyone kills unlawfully a slave or a servant-girl belonging to someone else or a four-footed beast of the class of cattle, let him be condemned to pay the owner the highest value that the property had attained in the preceding year' (Lex Aquilia, in The Digest of Justinian, 9.2.2; cf. also 9.2.5.22). In addition to providing mankind with wool, milk, and cheese, sheep also played an important role in spectacles and sacrifices. Sheep were sacrificed to many deities, including Jupiter, Juno, Janus, Mars, Terminus, Faunus, and Silvanus and were included in large state-sponsored sacrifices to the gods. ${ }^{13}$

11 In early Roman culture, goats were associated with victory, intelligence and even voraciousness. Depicted for centuries, images of the sheep and ram indicated earthy qualities, see Toynbee 1973:126.

12 Bodson 1983:312-320.

13 Although many ancient cultures sacrificed animals to their gods, the Romans had a peculiar type of sacrifice called a suovetaurilia. This word is formed from the names of 


\section{Hellenistic and Roman culture in Antioch}

Historically speaking, Antioch during Late Antiquity is one of the best documented cities of the ancient world. ${ }^{14}$ Local information for the late $4^{\text {th }}$ century for instance, abound in the speeches and letters of the pagan Libanius; the writings of the Christian priest John Chrysostom, and the $5^{\text {th }}$ century letters and writings of Theodoret of Cyrus.

Numerous historical studies on the Roman period in Antioch highlight the wealth, economic and strategic development of this province. ${ }^{15}$ By the late $4^{\text {th }}$ century the gap between rich landowners and urban poor widened considerably. ${ }^{16}$ This is illustrated by the luxurious villas, decorated with some of the best figurative mosaics of the late Roman period. ${ }^{17}$ In material terms, the city reached an apogee in the $5^{\text {th }}$ century, and it is from this time that our mosaic originates. The style of the Roman remains has an inherited independence from Rome and an origin in the Hellenistic architecture of Antioch. Art and architecture in this region was a provincial reproduction of Greater Antioch, in the work of a people steeped in the Greek traditions. ${ }^{18}$

One of the fundamental characteristics of the Early Byzantine period, however, was the adoption of Christianity as the official State religion. Consequently, the period saw the addition of mosaic art to a new functional setting - the Church - and the emergence of a Christian elite as public and private sponsors. Several scholars have argued that the period when a number of the villa

three animals, the pig (sus), sheep (ovis) and bull (taurus). In practice, the animals sacrificed seem to have all been male, so that the sheep was actually a ram. Its curved horns are visible in many artistic representations of this ritual. For a more complete analysis of this ritual and artistic representations see Toynbee 1973; Jameson 1988:87-119; Gilhus 2006:76-84.

14 Cabouret, Gautier \& Saliou 2004. This is the city we know from the famous description that closes discourse 11, On Antioch delivered by the rhetor Libanius c. AD 360 (Lib. Or. 11.196-272).

15 The history of Antioch was studied thoroughly by many a scholar, not the least of which was the 19th century Karl Otfried Müller, whose Antiquitates Antiochenae were published in 1839. A major work however has been written by Downey, 1961.

16 All indications towards the organisation of Antioch's rural production point towards a certain level of diversity. Once again, the best evidence is from later antiquity. Clarke 2003:185-188, indicates the coexistence of tenancy, possibly including requirements for the tenant to provide labour, seasonal labourers, sharecropping, but also independent peasants.

17 Morvillez 2005:271-287. For further information on the mosaic floors of Roman Syria in general and Apamea in particular, see Balty 1977, and 1986.

18 Kondoleon 2001. 
pavements were laid - the $6^{\text {th }}$ century - corresponded to the Justinianic era in which art underwent a 'Classical Renaissance'. ${ }^{19}$

\section{Iconography of sheep in Greco-Roman art}

The possession of sheep was of primary importance to ancient Roman society. Tradition had it that sheep were the first animals to be domesticated, 'both because of their usefulness and because of their mild nature' (Varro, Rust. 2.1.4). The depiction of a sheep in our mosaic is subject to different hypotheses, since this animal was represented in the earliest instances of Greek art. ${ }^{20}$ Depictions of sheep, rams, lambs and mutton were frequently encountered in all facets of Greek and Roman art from antiquity. The characteristic depiction of the animal appeared either in bucolic scenes, or in mythological narratives.

In addition to the depiction of sheep in the naturalist representations of Minoan and Mycenaean art, sheep also appeared systematically on vessels of the classical and Roman periods. Famous references to both wool and sheep from the ancient world include Jason's quest for the Golden Fleece (Fig. 3), Ulysses escaping from the Cyclops by clinging onto the underbelly of a ram, and Penelope's nightly unraveling of her weaving to keep suitors away until Ulysses returned.

Fig. 3: Jason bringing Pelias the Golden Fleece, Apulian red-figure calyx krater, c. 330 BC, Louvre Museum K 127, Paris. Source: Marie-Lan Nguyen (2006).

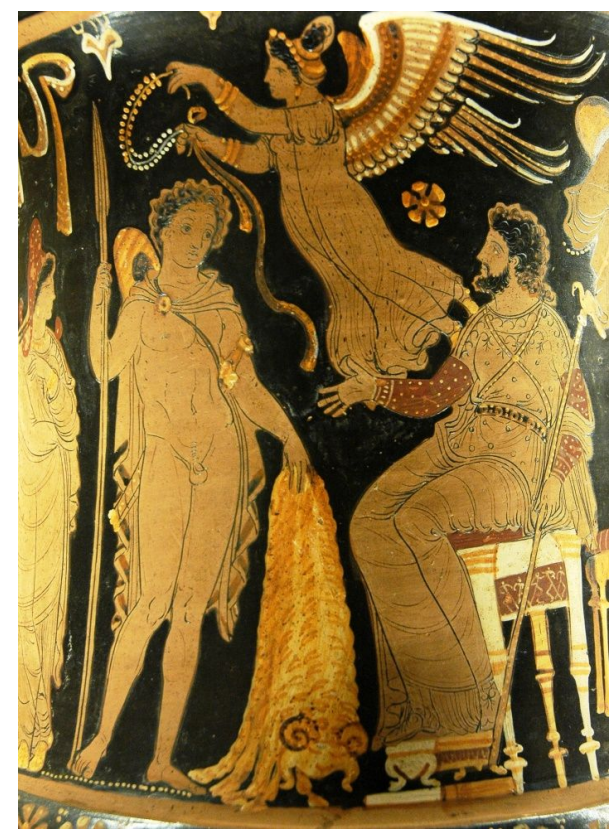

19 Whittow 1990:3-29, is the main representative of this view.

20 As a result, the Seleucids fostered the concept of a 'Syriac ethnos', in which all Aramaic speakers were included. These, Syriacs, were allowed to maintain social and cultural autonomy by developing their own communities within the Empire. This system of separate communities allowed Greeks and Syriacs to preserve the unique ethnic identities even when they inhabited the same topographic space. Caubet 2002:211-234. 
In artistic representations of Greek and Roman antiquity, sheep appear more frequently in pastoral scenes. There are a number of representations of pastoral life with sheep in several scenes that give detailed evidence of all activities involved, ranging from grazing to mythological scenes. ${ }^{21}$ For example, in Greek pottery the god Dionysus is sometimes portrayed wearing a sheepskin. Another mythological scene, depicted on murals, as well as ancient pottery, show Odysseus escaping from Polyphemus, concealing himself under the belly of a sheep. The figure of Odysseus in particular, features in the art, especially during Roman times, in frescoes and sculptures from Pompeii. The depiction of Phrixos and Helle, one of the most frequent scenes in Greek mythology, often features a sheep (Fig. 4). The following Pompeian fresco shows Phrixus and Helle rescued by a flying sheep with golden wool sent by Nephele, their natural mother (Hyg. Fab. 1-3, 12).

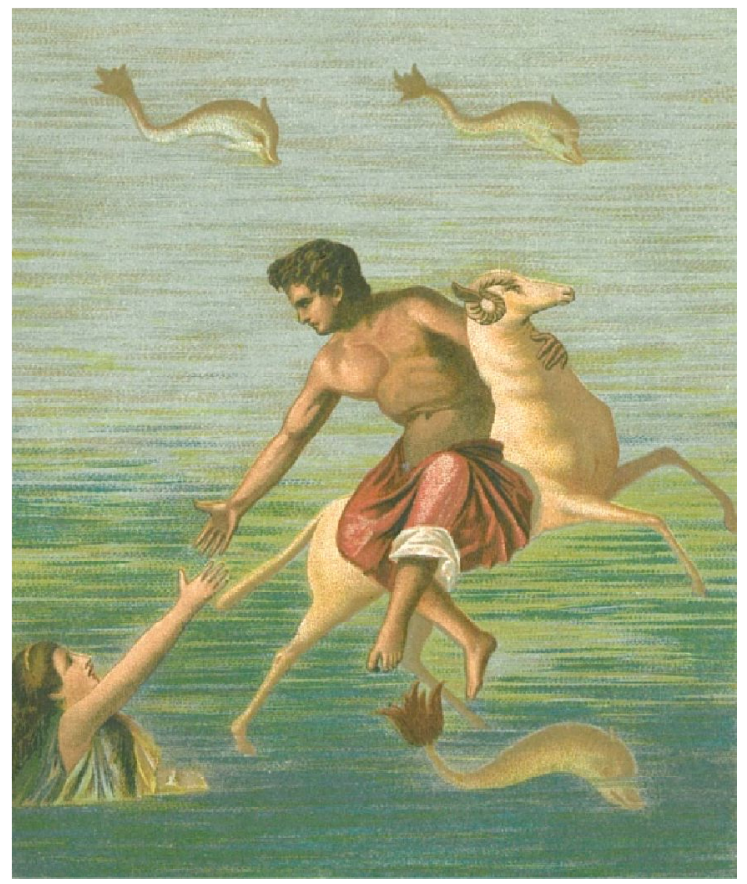

Fig. 4: Phrixos and Helle (45-79 BC). Reconstruction from ancient roman fresco found in Pompeii, Masseria di Cuomo (Insula Occidentalis VI, 17). Source: Immanuel Giel (2007).

21 Boardman 1975:89-93, cites and discuss some of these examples. 
Votive figurines were extremely popular in the Eastern provinces of the Roman Empire, where they were used as offerings, symbolically representing animals sacrificed at festivals (Fig. 5). However, evidence suggests that such offerings may also symbolically represent deities associated with specific animals and, perhaps, even the deities themselves, rendering this precious statue all the more significant as a sacred and archaic icon. Roman culture considered the sacrifice of animals as an act of propitiation or worship in order to placate the gods and no doubt sheep where included amongst the animals deemed suitable as sacrificial offerings. Animal sacrifices including sheep also served other significant religious purposes other than appeasement, such as an offering of thanksgiving, to seek a favour and as a way of telling the future such as the use of animal entrails for divination.

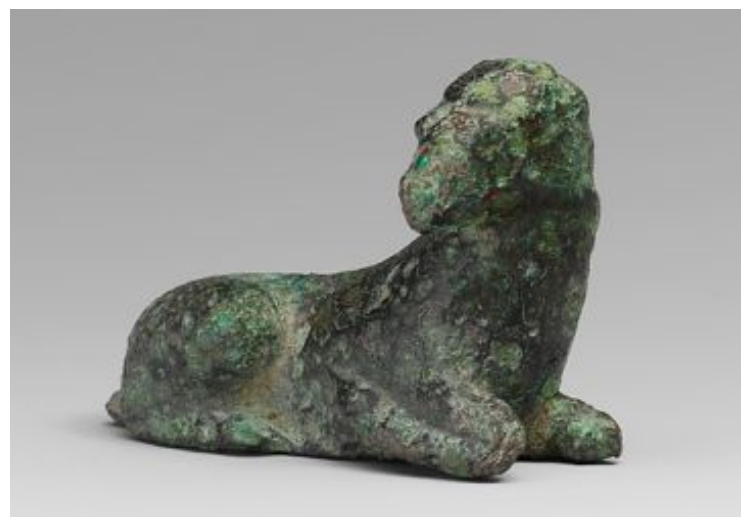

Fig. 5: Bronze statuette of a sheep, $6^{\text {th }}-5^{\text {th }}$ century BC. Source: Helen H Mertens (1977).

\section{Greek and Roman influences in the mosaics of Antioch}

The Roman heritage was so important in the city that the number of mosaics with pagan subjects in Antioch acquired an artistic quality. In addition, the Roman artists had specialized in the representation of animals due to the prevailing pastoral culture. From the splendor of public animal shows in the capital of the Empire, the representation of animals in the mosaic genre was relatively common. In this way, from scenes with mythological narration and those with festive motives, Roman artists developed a great talent to portray animals in various ways. In Antioch, there were numerous mosaics with bucolic themes that depicted animals such as sheep. For these reasons, it is essential to understand the pastoral 
and bucolic Roman culture that was so decisive in the formation of the aesthetics of Christian mosaics in the churches of Antioch. It is thus possible to discern a basic divide between villas on the one hand, with their scenes from Classical mythology, and, on the other, religious buildings whose mosaic pavements frequently depicted a combination of rural scenes.

Mosaics floor pavements offer a wealth of visual information from the Roman world..$^{22}$ Because mosaics offer such a popular means of visual display, the figures and animals portrayed provide a visual history of a range of social levels from Roman Syria and Palestine. ${ }^{23}$ The elite of Antioch fashioned an opulent domestic realm for social rituals that displayed classical learning and evoked what must have seemed to be the eternal tradition of Greco-Roman culture. ${ }^{24}$ Through the artifice of mosaic, they presented images that connected viewers to myths. Antioch's rich history and location allowed it to develop a diverse and unique culture based on both Greek and Roman influences.

\section{The iconographic subject of our mosaic is Paradise.}

Both the Greco-Roman and Christian culture had a definite idea of Paradise. The paradisiacal vision of Greco-Roman and Christian culture shared some common denominators. Both visions were characterized by an idyllic view of the vegetation and animals living there. The idea of paradeisos had its origin in the Middle and Near East. The term is a Hellenized version of an Avestan-Persian word (pairidaêza) which means 'park', 'garden', 'place made mild by the intervention of man', punctuated by wide variety of plants and animals. Indeed, it is this sense that becomes apparent in the biblical Eden described in Genesis. It is a Persian loanword but the word pardes is not used in the Hebrew, it is used in its Greek form in the Septuagint. Animals were a constant motif in Christian iconographic representation of Paradise, and they accompanied many scenes of the early Christian communities. For example, the Good Shepherd was also a recurrent

22 The analysis of Dunbabin 1999, reveals the vision that the most powerful citizens had regarding these subjects, as it was mainly the elite classes who commissioned them for their domestic and private spaces.

23 For an introduction to the art, culture, history, and discovery of ancient Antioch, see Kondoleon 2000. For earlier accounts of the discovery and identification of the mosaic floors of Antioch, see Morey 1938 and especially Levi 1947.

24 Since the publication of Haddad 1949:67-79, it seems clear that the Roman emperors favored the city from the beginning, regarding it as a more suitable capital for the eastern part of the empire than Alexandria or Constantinople. As a center of intellectual life it was also an arena for tensions between pagans and Christians. Therefore, Antioch can be considered as a model for contemporary discussions about megacities, especially with regard to governance and mixed populations. 
topic in Christian iconography where sheep were always present. The mosaic from the Mausoleum of Galla Placidia in Ravenna is a good example of how the figure of the sheep became a constant iconographic motif in Christian imagery (Fig. 6). Consequently, we must affirm that the presence of a sheep in a mosaic of an early church in Antioch can not seem unusual. According to E Kitzinger, a number of $6^{\text {th }}$ century mosaics clearly exemplify Classical stylistic traits. ${ }^{25}$ He points out, for example, that the mosaics of the Church of San Vitale in Ravenna (c. 550) display a sense of lushness in contrast to a stark geometry.

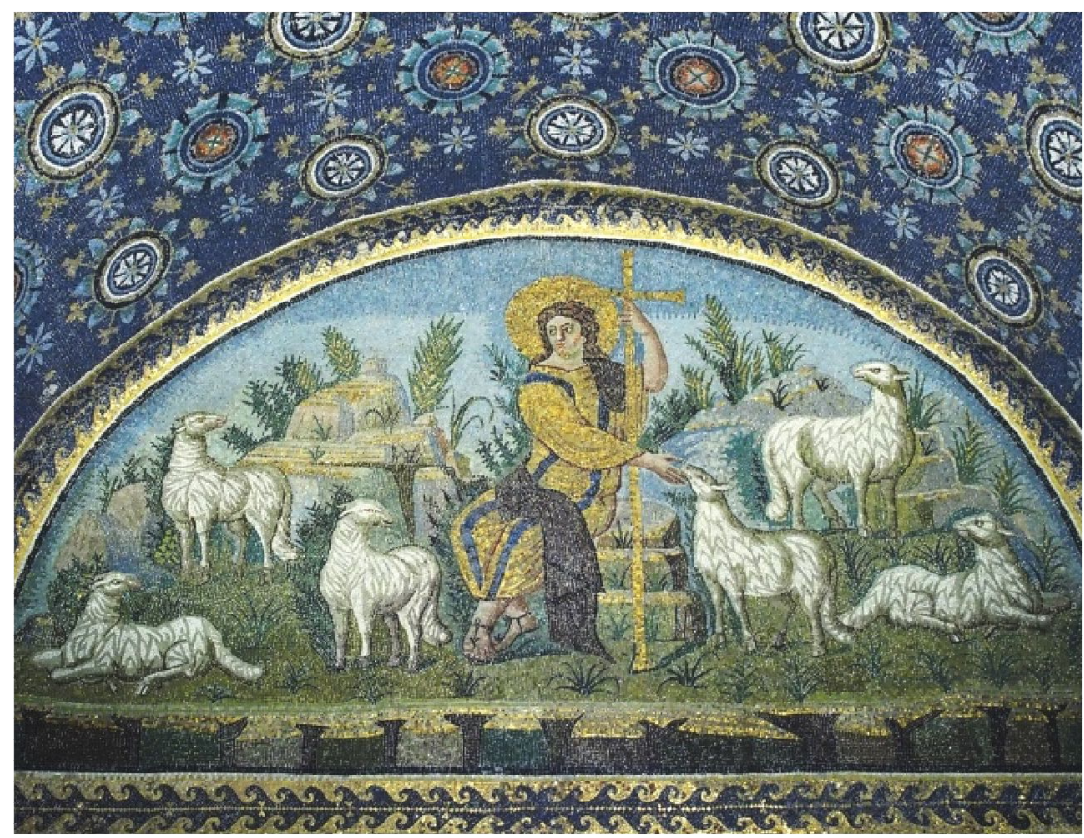

Fig. 6: Good Shepherd Mosaic, Mausoleum of Galla Placidia in Ravenna, c. 425. Source: Petar Milošević (2005).

In the cultural context of Antioch, we can identify some pagan iconographic subjects that had to represent sheep. Perhaps the most important of them was the subject of Orpheus. Animals always appear surrounding the figure of Orpheus in the mosaics of Antioch (Fig. 7).

25 Kitzinger 1977:81-98. 


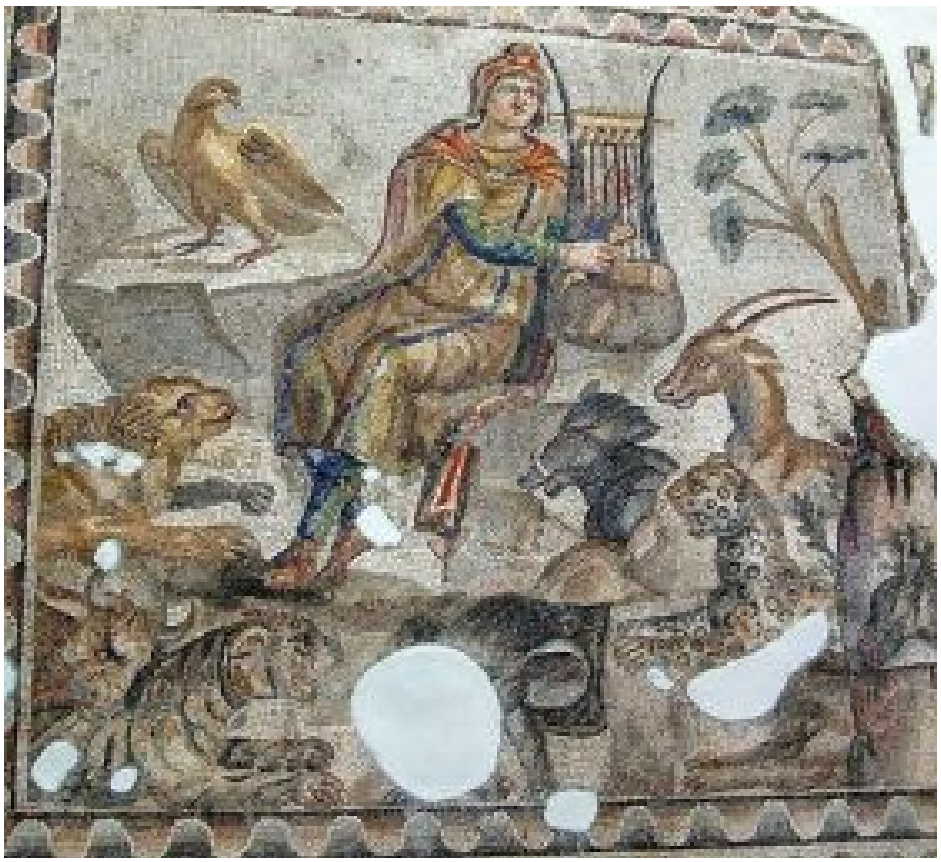

Fig. 7: Orpheus and the beasts. $3^{\text {rd }}$ century mosaic from Tarsus, Antioch. Source: María Luz Neira (2003).

Orpheus mosaics are found in several contexts throughout the Roman Empire. Orpheus was a popular subject in classical art, and was used in Early Christian art as a symbol for Christ. ${ }^{26}$

Orpheus soothing the animals is the most common iconography in this myth. Orpheus is depicted as young, beardless, long-faced, and looking into the distance. Usually he appears sitting on a rock. In a mosaic from Gaza, apparently, he sits on a throne and appears haloed (Fig. 8). Sometimes the seat is difficult to identify and he seems to be sitting in the air. In most of the mosaics, he has a lira or cythara on the left side, and a plectron on the right. He wears a long chiton and sometimes a robe. ${ }^{27}$

26 Murray 1981:46, they are both resurrection figures. Christ rose from the death and Orpheus also returned after a violent death, besides his own resurrection.

27 LIMC 1577, 2413, 4697, 16637. 


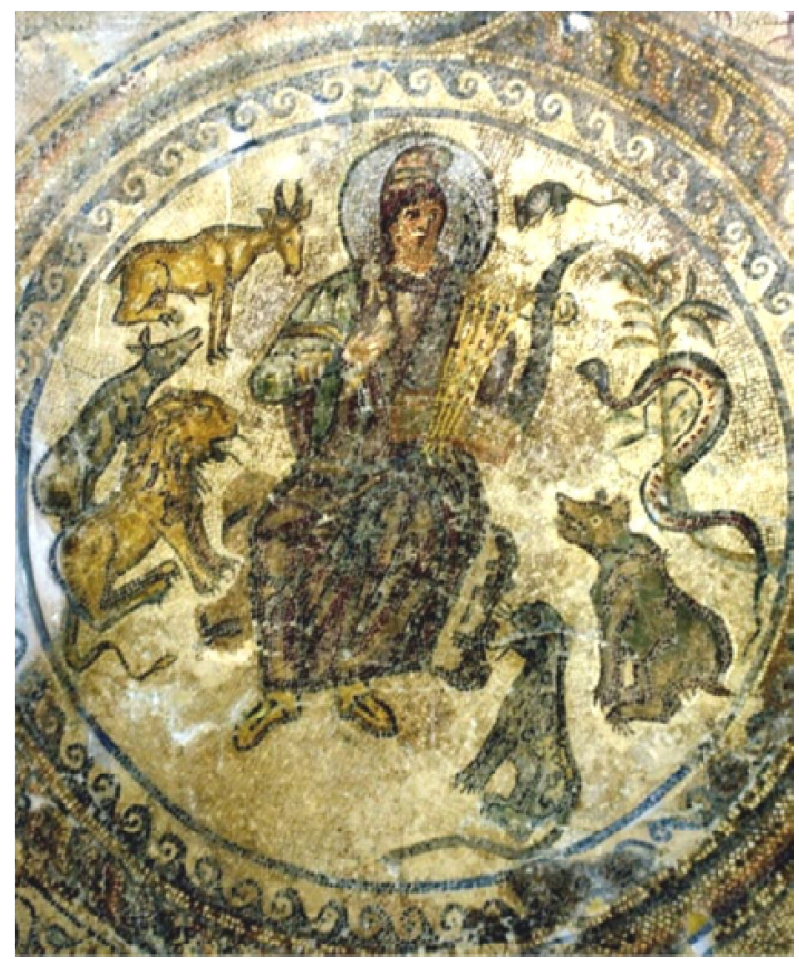

Fig. 8: Mosaic with Orpheus. $4^{\text {th }}$ century AD, Gaza (Ptolemais). Source: María Luz Neira (2004).

In addition to this iconographic tradition, there was another strong iconographic influence in Antioch, which could be important in the aesthetics of the Christian mosaics. In the agricultural area of Antioch, there were a significant number of Roman villas. In these villas, especially in the triclinium, Roman artists had created a huge number of mosaics related to the agricultural and pastoral world. Possession of animals grazing in the context of economic activity was fundamental for this new social class enriched every day was more powerful in Antioch. The type and number of people coming to the home residence would have been determined by the position taken by the employer. Together with customers, visitors to the residence included friends and co-patrons of the upper class, guests drinking, dining and entertainment. During the period of late antiquity, guests would constantly visit the aristocratic families, so habitual residence in a place of social interaction. In this context it was common to find images scattered in various 
places of the villages where the dominus was showing the quantity and quality of livestock, where sheep were sticking by its variety of natural and economic resources as a source of wealth. ${ }^{28}$

Mosaics of the $2^{\text {nd }}$ to $4^{\text {th }}$ centuries are located mainly in private homes. The most represented topics in these domestic contexts focused on mythological scenes, personifications of abstract ideas, and scenes of everyday life. ${ }^{29}$ The subject of our mosaic is perfectly suited to these new trends for abstract style in decorating the floor, lack of time references or landscape, and the richness of color and masterful use of light and shadow. Dunbabin describes how the emphasis on reception and entertainment of guests dominated the design of the residence. ${ }^{30}$ This is indicated not only by the mosaic's place in public rooms, but also for its rich design and content. In Antioch, the presence and proportions of the villas are very prominent in the late $4^{\text {th }}$ and early $5^{\text {th }}$ century. ${ }^{31}$ Hunting scenes and pastoral scenes were main features in the mosaics of the villa and became commonplace in the iconographic repertoire used by the dominus.

The mosaics of Antioch show us how the classical art of Greece and Rome evolved into the Christian and how people lived in this ancient city prior to its destruction by catastrophic earthquakes in AD 526 and 528. Many of the iconographic motifs found in these mosaics depict popular themes for the workshops of Roman mosaics. ${ }^{32}$ Figurative representations of ideas that were

28 Hales 2003:8, emphasizes that the relationship between town and country, in domestic terms between domus and villa, has received less attention than the complexities that even cursory attention demonstrated the topic might have deserved. Literature was insistent on differentiating the domus as seat of a family's Romanitas from the villa, a haven for un-Roman behaviour.

29 Balty 1977:75, draws a brief repertoire of the main themes of the mosaics, noting that gods, goddesses, and lesser powers live in statuary, temple decoration, and countless mosaics feature in domestic and public spaces. It is really interesting how Zeus, Apollo, Calliope, and the like may have received eviction notices that force them ostensibly from their ancient homes, but they never abandon Antioch.

30 Dunbabin 2003:56.

31 Rossiter 1989:101-110. On the composition, layout and parts of a Roman villa see Stat. Silv. 4,4. Cf. also Flor. 1, 5, 6-7; Hor. Carm. 3, 29,6-8; Juv. 14,87-90. Vitruvius treats foundations in connection to towns $(1,5,1)$, temples $(3,4,1-2)$ and theaters $(5,3)$ and recommends solid ground or digging until solid base is found. Chapters 6, 8,1 deals with the stability of the building and the importance of good foundations. Colum. 1, 5, 9-10 gives advice on how to build a solid foundation on a slope.

32 Mosaicists from Homs (ancient Emesa) established ateliers at Shahba-Philippopolis and began the outstanding pavement production in that town (newly founded by Philip the Arab), a development lasting for a few generations, Huskinson 2002-2003:131-165. The Roman colony of Philippi, Colonia Victrix Philippensium, was founded after the battle of Philippi in 42 BC (Strab. Geogr. 7.331). The earliest known mosaic, a blackand-white pavement which no longer survives, was located beneath the $2^{\text {nd }}$ century AD. 
important to ancient Romean culture, like life, luxury, safety, joy, security, virility, power, hope, abundance or fertility. ${ }^{33}$

Houses, villas and churches were richly decorated with works of art in the form of mosaics. ${ }^{34}$ Lavin emphasized that North African mosaicists repeatedly approached the floor area as a consistent unit, and that this conception manifested itself in a variety of compositional types. Essentially, the first indication of a departure from the traditional concepts in the Near East was apparent at Antioch in the $4^{\text {th }}$ century. Most of the mosaics of Antioch residences have figurative compositions. ${ }^{35}$ Reviews of current experts agree that the motifs found in private mosaics exhibit specific requests that commissioned the work. ${ }^{36}$ The $4^{\text {th }}$ and $5^{\text {th }}$ centuries did bring a number of important developments in Antioch, largely in the direction of the unification of the soil surface. After the pictorial richness and variety of the time of Constantine, the number of floors with figurative subjects decreased in favor of purely abstract designs. ${ }^{37}$ There is no reason to suspect that this style too, so hostile to the Hellenistic and humanistic tradition that had characterized so far Antioch, was an import. Then, in the second quarter of the $5^{\text {th }}$ century Antiochene artists set in yet a new direction.

The black-and-white style developed in Italy during the $1^{\text {st }}$ century $\mathrm{BC}$ and prevailed throughout most of the empire until the middle of the $2^{\text {nd }}$ century $\mathrm{AD}$. The example from Philippi, however, is the earliest black-and-white mosaic pavement to date found in Greece and comparable motifs can be identified in pavements from Italy, the Western Empire at large, and the Hellenistic east. Dunbabin 1999:55-57.

33 A repertoire of these subjects was established by Campbell 1988:78-98.

34 Excavations conducted in 1932-39 in Daphne and Antioch uncovered a large number of fine mosaic floors from both private houses and public buildings. Dating largely from the Roman imperial period, many of the floors represent copies of famous ancient paintings that otherwise would have been unknown. The most complete analysis was made by Stillwell 1961:47-57. Later contributions from Hales 2003, contributed to enriching this subject.

35 It seems essential in this sense to follow the guidelines of Balty 1986:395-406, when he emphasizes that it is equally important to consider the formal context in which the specific motifs and themes occur. The general compositions into which they are arranged are also of Oriental origin, still less the underlying attitude toward the floor that made them useful and attractive to Antiochene artists at this particular period. Kitzinger 1951:66-74, notes the very striking similarity of composition between the Striding Lion Mosaic from Antioch, and a tapestry in the Textile Museum in Washington, DC (no. 71.33).

36 Among them see Morey 1938:33-46.

37 The Antioch mosaics amply demonstrate the tenacity of Hellenistic pictorial tradition there through the early $4^{\text {th }}$ century; and, considering the almost iconoclastic predominance of abstract designs in the period that followed, the late $5^{\text {th }}$ century hunting and animal pavements with their elaborate figural compositions seem actually to have revived that tradition in a new guise. Lavin 1963:274. 


\section{Roman pastoral life and visual culture}

Pastoral scenes of the kind commonly encountered on the ecclesiastical pavements of Arabia and Palestine in the Early Byzantine period may be viewed as more specifically evoking Psalm 23, whose first two lines read: 'The Lord is my shepherd; I shall not be in want. He makes me lie down in green pastures ...' Pastoral scenes could also be regarded as referring to John 10:11: 'The Good Shepherd lays down his life for his sheep'. This kind of symbolism may be an appropriate explanation for pastoral scenes in the ecclesiastical context together with hunting scenes.

The presence of sheep in Christian mosaic has various sources of influence. First, their presence is justified by the idyllic vision of the Christian Paradise, where the animals had an outstanding importance. Second, Roman culture was characterized for centuries by a clear pastoral vocation. In Antioch, these two traditions met: the Christian tradition that gave rise to represent Paradise in the mosaic of a church, and the pagan tradition, which offered imitation models that, were present in the city for centuries.

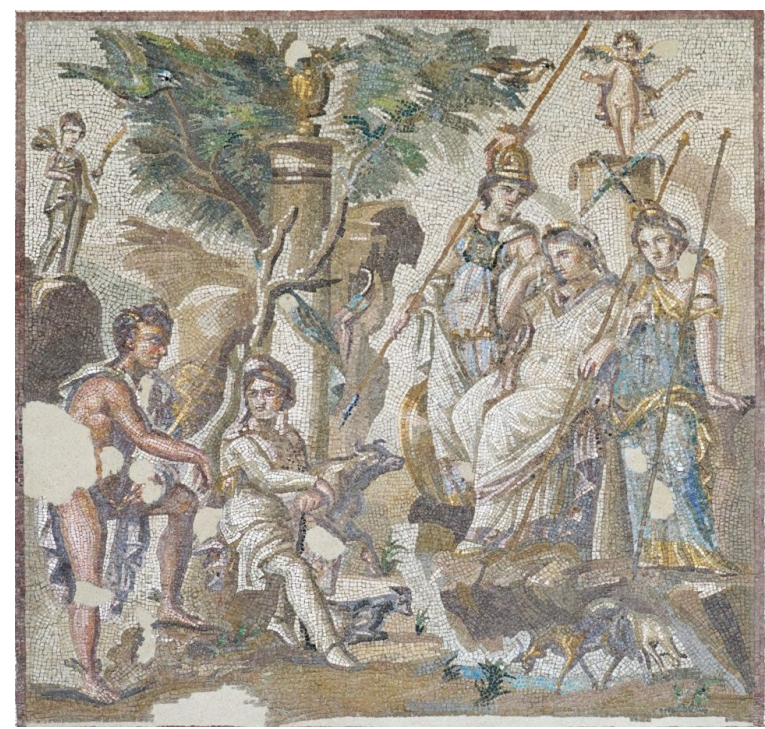

Fig. 9: Judgement of Paris, AD 115-150, Louvre Museum Ma3443, Source:Marie-Lan Nguyen (2010).

The iconographic representation of the Christian Paradise was not much different from some pagan subjects. For example, the Judgment of Paris (Fig. 9), from the 
Atrium House triclinium in Antioch-on-the-Orontes, was represented in the mosaics of Antioch, whose iconography required the presence of grazing animals such as sheep.

The repeated appearance of the motif of the paradisiac life in one or two generations of Roman poets in the last years of the Republic and the first decades of the Empire is to be seen against the background of the social, political and economic chaos following in the wake of the civil wars. The second book of the Georgics (2.513-516) shows us the ideal existence as Vergil conceives it by now: the petty farmer's life in the Italian countryside, ${ }^{38}$ The poet strongly emphasizes peacefulness, security and undisturbed news of this kind of life, in contrast with the useless luxury and the crowds of the city. The elegiac poets, Propertius (4.1.1-4), Tibullus (1.3.39-42; 45-46) and Ovid (Fast. 1.243f.), obviously liked the contrast between proud and brilliant modern Rome and the rural simplicity of small settlement.

A quality traditionally ascribed to sheep and goats also contributed to the idea of sheep spontaneously offering their milk to early man. Vergil tells us in the Georgics that the goats 'herded remember to come home, they lead their young and hardly lift their heavy udders through the half-door' (3.316). In Horace's dream, in which he longs not for the first days of mankind but for some far distant imaginary islands, goats are substituted for sheep (Epod. 16.43-50). The topic in itself is traditional, with several motifs known from Homer (Od. 4.563-569), Hesiod (Op. 112-120), Pindar (Ol. 2.75-85) and other classical utopias. ${ }^{39}$

The literary genre best suited to the pastoral and bucolic atmosphere is definitely poetry in the Roman world..$^{40}$ Columella describes the care of animals on a Roman farm. The management of oxen, bulls and cows, horses, mules and asses, sheep, goats, pigs, dogs, as well as different types of farm birds and fish in the fishponds is explained. For example, Columela includes extensive instructions for handling various animal species (Rust. 6-9). His description shows the variety of animal life on a farm and diversity in food production, in which different types of animal husbandry with other types of food production combined. The Roman poet Lucretius in his poem about the history of civilization, On the nature of things, is responsible for contrast with domestic wild animals like dogs, pack animals, sheep

38 His pastoral images reflecting on human nature and progress are ruled by primitivism and allude to a much desired, yet unachievable past. Vergil specifies the locus of this ideal pastoral life, which originates in Hesiod and was revived many centuries later in the bucolic verses of Theocritus, as Arcadia, $c f$. Forbes 1954:103. For the idea of the 'noble savage' in antiquity, see Lovejoy \& Boas, 1997.

39 Boyle 1975:34-67.

40 Schiebe 2004:141-145, nowadays scholarship tends to interpret pastoral by discarding the sense of fiction and convention surrounding the genre. 
and cows: 'First, the fierce breed of lions, that savage tribe, has been protected by the courage, the wolf by cunning, by the speed of deer. But the smart dog, so light sleep and so true heart, workhorses of all kinds, sheep also wool, and races horned oxen, all of them are in charge of the protection of men, Memmius' (5.864-70).

As we have shown, animal subjects in a pastoral context were common in the mosaics of Antioch in the $5^{\text {th }}$ century. ${ }^{41}$ This iconographic tradition is the result of centuries of animal's pastoral culture and the Roman Empire. Classicals sources show clearly the importance of animals, countryside or grazing in relation to the culture that is generated from this world to the Roman city. Indeed, there is a large body of evidence for pastoral subsistence in the Roman period. It has been rightly argued, however, that in the Christian period pastoral scenes took on an increasingly symbolical meaning. Levi has drawn attention to the frequency of depiction of pastoral scenes (often located beneath the busts of the dead) on sarcophagi, contending plausibly that this was connected with the 'Good Shepherd' ${ }^{42}$

The origins of the pastoral scene may be traced back to the idyllic-pastoral repertory of Hellenistic art. One of the first mosaics that clearly demonstrate this pastoral vision of nature is a tesselated mosaic floor from a Roman villa at Corinth, depicting a pastoral scene (c. AD 150 - 200) (Fig. 10).

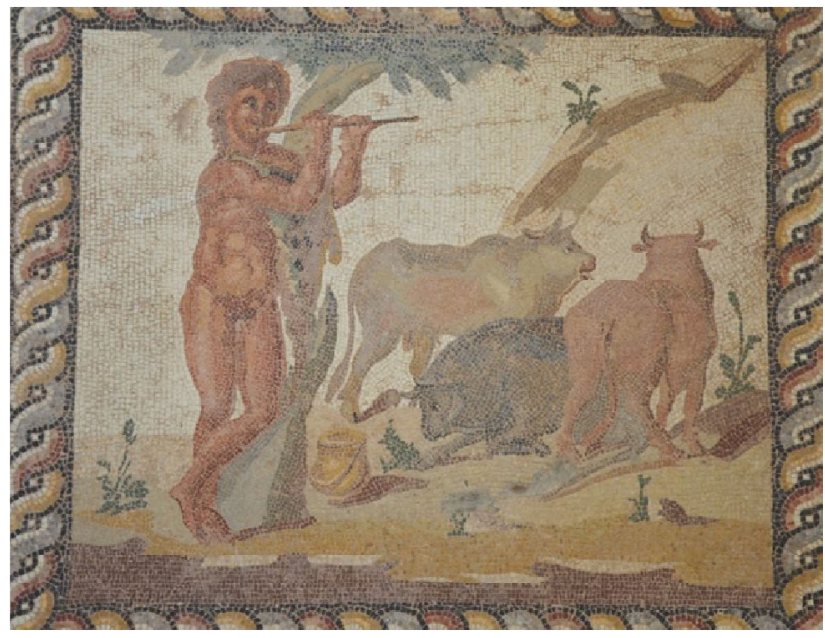

Fig. 10:

Tesselated mosaic

floor from a

Roman villa at

Corinth, depicting

a pastoral scene,

c. $A D 150-200$.

Source: Carole

Raddato (2015).

41 Kondoleon 2005:45-56.

42 Jensen 2000:37, it is possible to add some more value to this iconographic representation, since 'in late antiquity, the image of the sheep could have developed a more generic meaning of philantrophy, or humanitarian care'. 
In North Africa, the presence of animals in mosaics took place early, especially in the context of hunting and gladiatorial combat. This kind of scene occurred in a set of emblemata in the Zliten villa (Fig. 11). It depicts gladiatorial contests, animal hunts, and scenes from everyday life. There have been various disputes related to the dating of the mosaic, mostly based on archaeological or stylistic comparisons. Art historian Christine Kondoleon supports an Antonine period dating because of the mosaic's multiple design elements. The Zliten floor mosaic employs tressed or braided twisted rope outlines to frame each panel, black backgrounds provide optical contrast and the panels alternate circular and square patterns. ${ }^{43}$

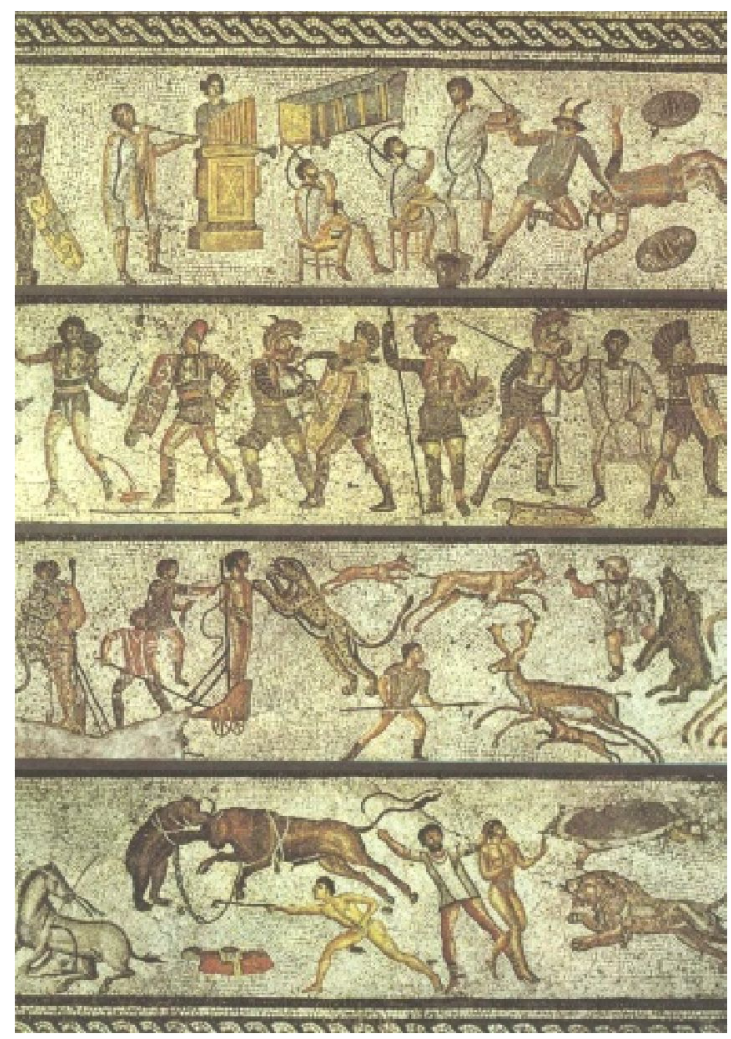

Fig. 11: Mosaic showing Roman entertainments from the 1st century, before AD 80. Jamahiriya Museum, Tripoli, Libya. From Dar Buc Ammera villa (Zliten).

43 Kondoleon 1995:73-74. 
In the Provinces of Arabia and Palestine, a number of examples from the Mount Nebo and Beth Shean areas contain similar scenes to those described above. In the Church of the Holy Martyrs Lot and Procopius (Fig.12), the vine rinceau encloses a shepherd resting on his stick, one end of which rests under his armpit, as well as two grazing sheep. ${ }^{44}$ This theme is regarded as representing the dominion of Mankind over beasts, in the depictions of humans combating animals. The eastern panel is decorated with hunting, pastoral, and winemaking scenes; all enclosed in twenty volutes of vines arranged in six rows of four scrolls each. The four vines proceed from the four corners of the field, each from a clump of acanthus leaves. The western panel is decorated with four fruit-laden trees placed in the four corners and meeting in the center. Pairs of animals facing each other are found among them. Among the animals are two bulls facing an altar; the inscription below them reads: 'Then they shall offer calves upon Thy altar [Psalm 51:21]. Lord has mercy on the lowly Epiphania.'

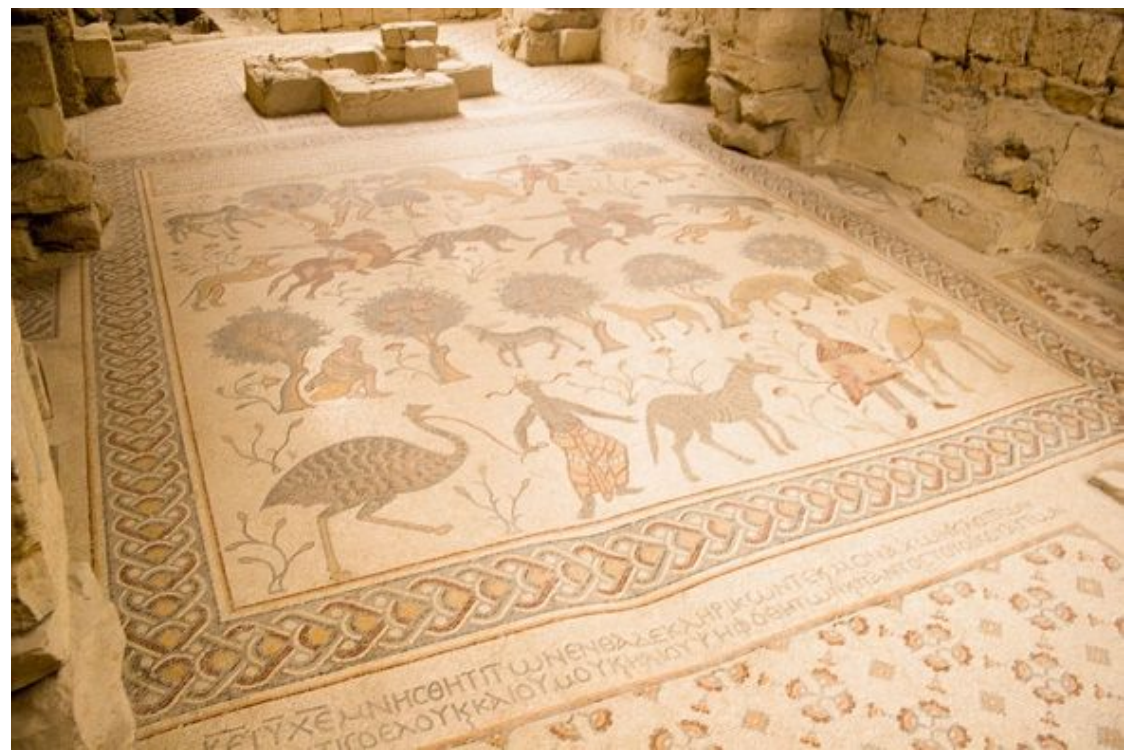

Fig. 12: Mosaics Church of the Holy Martyrs Lot and Procopius, Nebo Mountain. Source: Jerzy Strzelecki (2011).

44 Maguire 2012:65-88, posits that as elements of the natural world became more problematic for Byzantine artists and viewers, architectural motifs assumed a greater role in conveying symbolism in Byzantine religious art. 
Similarly, at Leptis Magna, in the Villa of Orpheus, a fragmentary panel of the Orpheus mosaic portrayed a milking shepherd watched by a bearded figure leaning on his stick, one end of which rested under his armpit (c. 150-200). A somewhat later mosaic from Carthage, the Mosaic of Dominus Julius, depicted a shepherd seated in front of his hut watching his flock (Fig. 13). Dominus Julius was a rich landowner who lived at Carthage, but the mosaic depicts his countryside residence. The overall purpose of the mosaic was to show the wealth of Julius in all its facets, including the clothes of his servants. This type of scene, akin to the rôle of the hunting scene, was designed to portray an element of rural activity on the villa estate and may be regarded as symbolic of the patron's wealth and prestige. The pastoral scene often accompanied other rural scenes, frequently hunting activity. $^{45}$

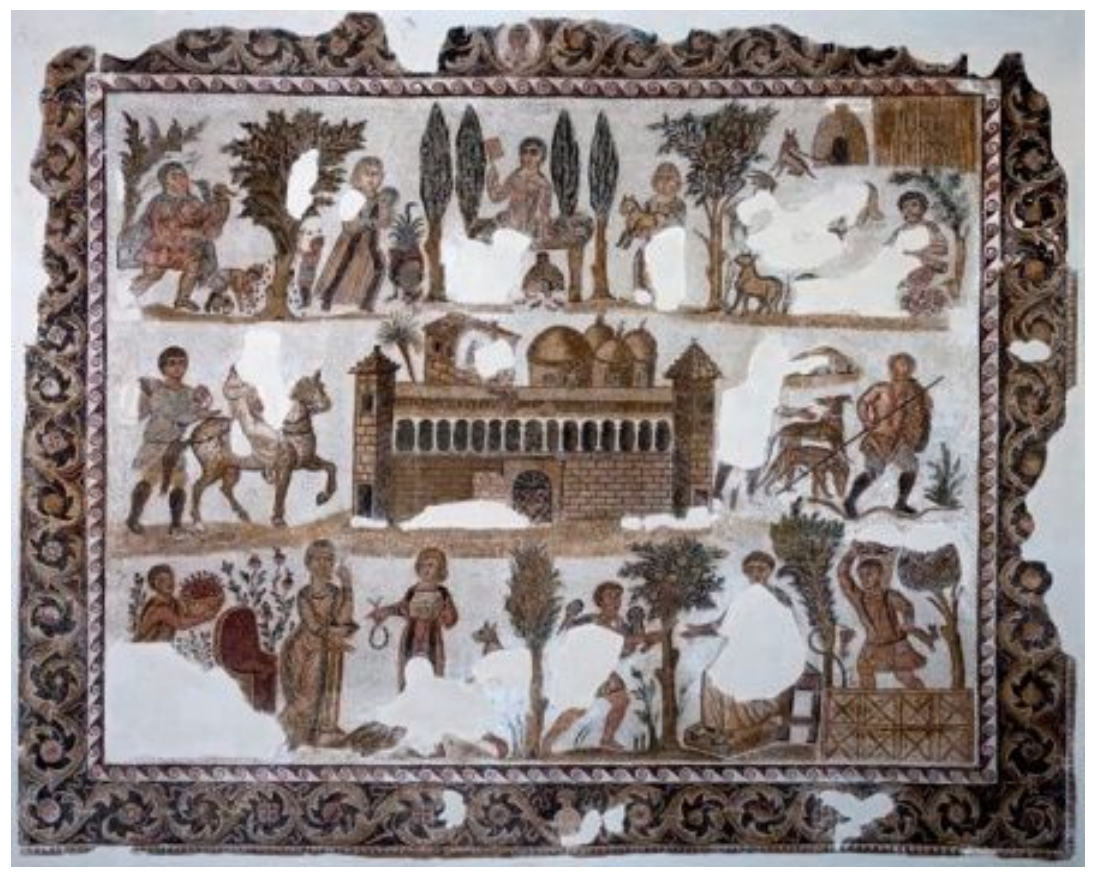

Fig. 13: Dominus Julius mosaic, late 4th century, Bardo National Museum. Source: Boyd Dwyer (2007).

45 Lavin, 1963:179-286, remembers that Roman paintings depict pastoral scenes with motifs of nature: mountains, trees, and also buildings. 
As mythological scenes declined by the $3^{\text {rd }}$ century, figures of personifications and hunting scenes increasingly graced private dwellings. ${ }^{46}$ Churches and synagogues, on the other hand, used agricultural, pastoral, and hunting scenes to decorate their floors. Because many mosaics in the $5^{\text {th }}$ century were built in churches and synagogues, more individuals performing a variety of tasks in pastoral and agricultural scenes were depicted. ${ }^{47}$ This provides us with figures from a wider range of social levels on which to see how everyday costume indicated status for the Romans. ${ }^{48}$ In addition to figurative scenes, animals were an important subject for the ancient mosaic artist, especially in North Africa and the Near East. They could be the subject of hunting, pastoral, or aquatic scenes. Beginning in the $5^{\text {th }}$ century rows of animals were spread freely over the surface to be decorated instead of being framed in neatly defined compartments. This style of mosaic pavement could be adapted shaped floor spaces, whether in a domestic or church context.

\section{Conclusions}

At Antioch, there was an iconographic dichotomy between ecclesiastical buildings, churches and villas. The proportion of excavated villas in Arabia and Palestine is low compared to the number of religious buildings, particularly churches, during the $4^{\text {th }}$ and $5^{\text {th }}$ centuries AD. Mosaics became characterized by patterns, which spread out over the whole surface and developed into geometric patterns popular in the provinces of Syria and Palestine from the $5^{\text {th }}$ century onwards.

Merrony proposed an iconographic dichotomy between religious buildings which often contained inhabited vine rinceau pavements, and villas which frequently exhibited mythological scenes. The pastoral scene developed from the idyllic-pastoral repertory of Hellenistic art and came to reflect a rural activity on the villa. The idyllic and bucolic Roman culture remained present in the Roman visual imagery in Antioch to the $4^{\text {th }}$ and $5^{\text {th }}$ centuries. The latter's origin was mythological, but like the pastoral scene it assumed a symbolical rôle, in this particular case embodying the virtus and prestige of the patron. ${ }^{49}$

46 The realistic narrative hunting scenes of the West are imbued with deep metaphorical significance in the eastern examples, as most directly attested in the Megalopsychia pavement at Antioch, $c f$. Levi, 1947:339 ff.

$47 \quad$ Hachlili 2013.

48 Bermejo Tirado 2012:101-115.

49 A relationship can often be found between the themes of floor designs and the function of the spaces they were intended to decorate. In oeci, for example, the owner might select a theme from mythology, literature, or daily life, while triclinia often featured drinking and banquet scenes, or general subjects from myth and legend. Bath suites often depicted themes associated with water and exercise, such as dolphins, fish, sea 
Subjects such the Judgment of Paris, or Orpheus calming the beasts, perpetuated the taste for animal iconography in Roman visual culture. This figurative presence in the images of primitive churches of Antioch contrast with the existence of a 'taste for the geometric' in late antique floor mosaics. ${ }^{50}$ Over many centuries in Antioch, a variety of subjects became popular, including mythological scenes, literary themes, hunting and pastoral scenes, and Christian imagery. A symbolical explanation for the pastoral scene in ecclesiastical buildings was also suggested, one which had specifically appropriated a Biblical significance.

Thus, the artistic context of Roman villas and triclinia were of extraordinary importance for the formation of the aesthetic taste of the early Christian mosaics in the early churches of Antioch. The villa was organized according to the reception of guests and seems to be made in order to impress them..$^{51}$ Dining rooms feature regularly in the study of soil-Roman mosaics. ${ }^{52}$ The decorations of the dining rooms, while projecting personal tastes of the owner, also participated in the function of the room as an area of feasting and entertainment. ${ }^{53}$ Levi suggested, for

nymphs (female spirits), or athletes, while bedrooms might feature mosaic floors depicting Venus and Cupid (the Roman gods of love). For a succinct overview on the context and meaning of mosaic floors within the Roman house, see Ling 1988:113-135.

50 Kitzinger 1965:341-352. The 'geometric style' was defined with reference to the geometric carpet mosaics of the Kaoussie Church, which are well dated by inscriptions to 387, the mosaic of the Synagogue at Apamea, dated by inscription to 391-392. Such geometric floors stood in stark contrast to the usual figural repertoire of mosaics from Antioch.

51 The orientation of individual rooms was as important as that of the villas. Ancient authors mentioned that the orientation of rooms was dependent on their function and time of use; for example, according to Vitruvius, cubicula and libraries should face east, because they needed the morning light. Spring and autumn triclinia should also look east, because the sun's course would render them temperate by the evening, when these rooms were used. Conversely, summer triclinia should look to the north so that they were turned away from the sun's course, and winter triclinia and baths towards the west because they needed the evening light (Vitr. De arch. 6.4.1-2.), see Kondoleon 1995:232-269. For a recent discussion of seasonal rooms in Roman villas see Cosh 2001:219-242.

52 Martz 2002:125.

53 Dunbabin 2003:125, based on Latin literature, explained perfectly how the qualities of a site might change the ideal situations outlined above and designers had to come up with solutions in order to deal with the 'problems' that arose on such occasions. On the one hand, the choice of a favoured position in the landscape was a privilege that one did not always have. For example, if one was forced to build a villa on the bank of a river, which Varro indicated was not an ideal position, the villa should not face the river as it would be extremely cold in the winter and unwholesome in the summer (Varro, Rust. 1.12.1; Vitr., De arch. 5.10.1). 
example, that scenes exhibiting a mythological theme, such as the hunting scene of Venus and Adonis (Fig. 14), tended to lose their mythological aspect in the course of the Roman period and gained in symbolic value by becoming genre-hunting scenes. ${ }^{54}$ They were important rooms of the house, where the employer could show visitors the unmistakable signs of their status and culture. Although many are in isolation, with little in the way of the walls from which to restore the building to plant around, it seems that the vast majority had decorated private homes. ${ }^{55}$

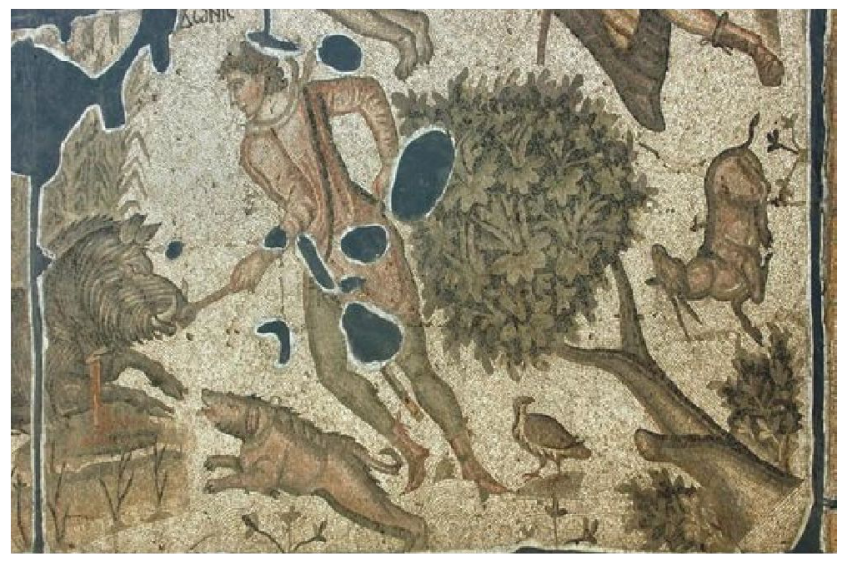

Fig. 14: Adonis hunting in the Mosaic of Megalopsychia, second half of the $5^{\text {th }}$ century AD, Antakya Museum 7518. Source: Dick Osseman (2004).

The last mosaic I will show, was excavated from a villa at Daphne, a resort in the hills above ancient Antioch, and depicts the hunting of dangerous game, an aristocratic pastime represented in mosaics and other media throughout the Roman world and commonly at Antioch (Fig. 15). At the center stands a hunter ringed by animals in a pattern much like that of an oriental carpet. Hunters on foot and

${ }^{54}$ In his discussion of composition in the Antioch pavements Levi 1947, pointed out that one of the significant characteristics of late antique style that makes its appearance in one of the pastoral scenes of the Constantinian Villa, is the tendency to arrange the elements in superimposed horizontal strips. Lavin 1963:226. Subsequently the device largely disappears at Antioch until it suddenly reemerges in fully developed form in the late hunting and animal pavement scenes, where it performs a major role in the surface organization by which these mosaics are marked.

55 The villa's underground triclinium provides exceptional evidence for the interplay between architectural design, interior decoration and landscape that characterised the cultural mannerism of the period, see Sandwell \& Huskinson 2004:73-77. 
horseback attack a variety of animals with sword, spear, and bow and arrow, a weapon used by Parthians and Persians to the east.

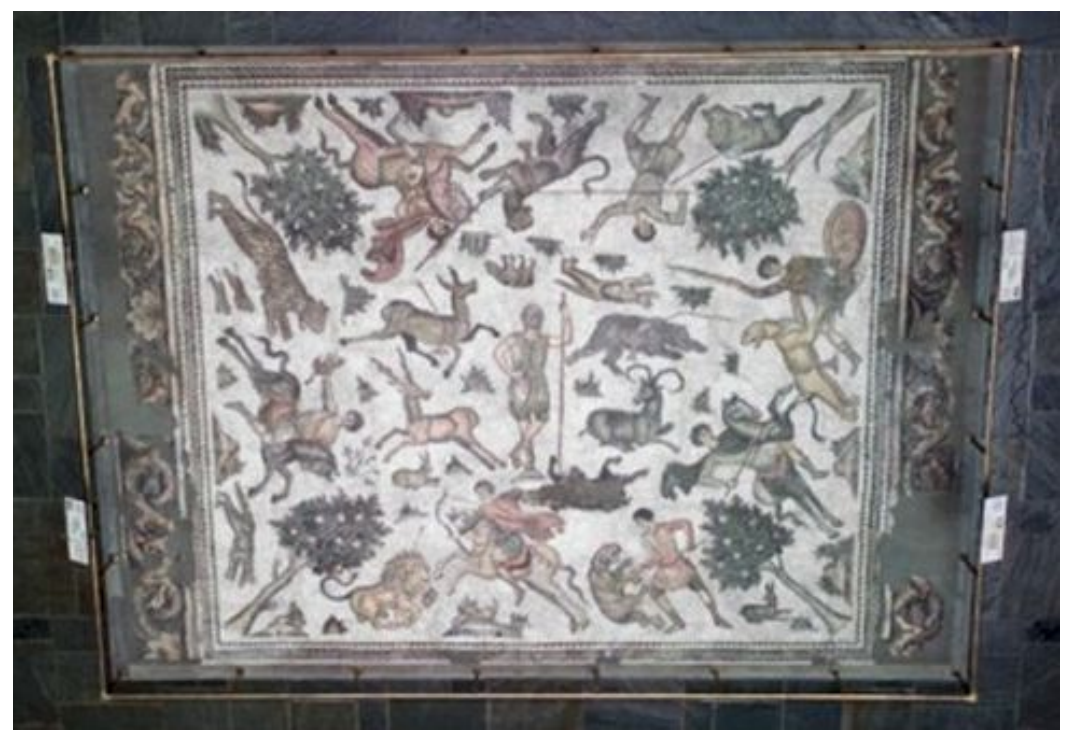

Fig. 15: Hunting Scene, Late Roman (Daphne), Mosaics created between $2^{\text {nd }}$ and $4^{\text {th }}$ centuries AD. Worcester Art Museum, Worcester, Massachusetts, USA.

The mosaics in the area of Syria and Palestine, therefore, derived from the same sources as their Roman predecessors. The Calydonian Hunt was frequently depicted on Roman sarcophagi, as well as on mosaic pavements, notably the Constantinian Villa at Antioch. ${ }^{56}$ The mosaic in the Constantinian Villa celebrates the wealth of the land by depicting the Seasons, which convey the attributes of the land's bounty at specific times of the year. The panels with scenes of tranquil pastoral life and of hunts with wild animals - bears, lions and leopards - also suggest the ideal attributes of the land. ${ }^{57}$ In addition, it may be that the mosaic of the Constantinian Villa acted as inspiration and as an object of imitation for some

${ }_{56}^{56}$ Levi 1947:611; also Morey, 1953:32, and 1938:38 ff.

57 The overall design of the triclinium of the villa and its meaning is perfectly analyzed by Neuenfeldt 2009:33ff. Previously Levi's study separates the panels into individual mythological motifs providing comparable sources from the traditions of classical Greek and Roman art. 
dominus who wanted to include iconographic themes and motifs in private residences. ${ }^{58}$

There is no doubt now that the Antioch mosaic artists had distinguished themselves by their adherence to the classical tradition..$^{59}$ The mosaics of the villas of Antioch contain scenes from pastoral life and hunting representations from the tradition of allegory and mythology. Their style is also very different from anything that had gone before, and contrasts with that of the hunts. In the pastoral panels, the treatment of space is more abstract, and the arrangement of landscape elements in registers introduces a system that became a feature of mediaeval art. In the early $4^{\text {th }}$ century, a new conception of the floor as a unit made its appearance. Subsequently, the new attitude is limited to designs of an abstract or quasi-abstract nature. Thus, the pastoral and animal pavements show an internal evolution of their own that presupposes an earlier development bridging the gap to the original Hellenistic tradition.

\section{BIBLIOGRAPHY}

Avi-Yonah, M 1932-1935. Mosaic pavements in Palestine. QDAP 2:136-181; 3:26- 72; 4:187-193; 5:11-30.

Balty, J 1986. Iconographie classique et identités régionales: Les mosaïques romaines de Syrie. In Iconographie Classique et Identités Régionales, $\mathrm{BCH}$, Suppl. XIX, París, 395-406.

1984. Les mosaïques de Syrie au ve siècle et leur repertoire. Byzantion 54:437-468.

1977. Mosaiques antiques de Syrie. Bruxelles: CBRAP. 1986. Mosaïques d'Apameé. Bruxelles: CBRAP.

Becker, L \& Kondoleon, C 2005. The arts of Antioch: Art historical and scientific approaches to Roman mosaics and a catalogue of the Worcester Art Museum Antioch collection. Princeton: Princeton University Press.

Belis, A. 2016 Roman mosaics in the J Paul Getty Museum. Los Angeles: J Paul Getty Museum.

58 Levi 1947:260 ff., fig. 100. The function of the room is still unclear, though it is referred to by modern scholars as a triclinium or tablinum, a hall displaying elements of family history, $c f$. Lavin 1963:190. The mosaic from the main room of the Constantinian Villa is divided into two sections: the square in the east and the rectangle to the west. In the middle of the square are the remains of an octagonal pool. Around the pool are four trapezoidal panels with hunting scenes. Separating the hunt scenes are figures of the four seasons - Spring, Summer, Autumn, and Winter. The border of the square features a meander key motif broken by scenes of pastoral life and six busts of personifications, Levi 1947:248.

59 Will 1989:567-580. 
Bermejo Tirado, J 2012. The social construction of gender identities through the ancient mosaics from Antioch. Le Mosaïque Greco-Romaine. Proceedings of XII conference of AIEMA. Bursa, 101-115.

Boardman, J 1975. Athenian red figure vases: The Archaic period: A handbook. London: Thames \& Hudson.

Bodson, L 1983. Attitudes toward animals in Greco-Roman antiquity. International Journal for the Study of Animal Problems 4.4:312-320.

Boyle, A 1975. Ancient pastoral: Ramus essays on Greek and Roman pastoral poetry. Berwic: Aureal Publications.

Butcher, K 2003. Roman Syria and the Near East. Los Angeles: Getty Publications (with the British Museum Press).

Cabouret, B \& Gautier, P \& Saliou, C 2004. Antioch de Syrie: histoire, images et traces de la ville antique. Paris: De Boccard.

Campbell, G 2014. The Oxford handbook of animals in Classical thought and life. Oxford: Oxford University Press.

Campbell, S 1988. The mosaics of Antioch. Toronto: Pontifical Institute for Medieval Studies.

Caubet, A 2002. Animals in Syro-Palestinian art. In Collins, B J. A history of the animal world in the ancient Near East, 211-234. Leiden: Brill.

Clarke, J 2003. Review: Finding lost Antioch: Exhibition, catalogue, programs. ABull 85.1:185-188.

Cosh, S 2001. Seasonal dining rooms in Romano-British Houses. Britannia 32:219-242.

Donceel-Voûte, P 1988. Les pavements des églises byzantines de Syrie et du Liban, Louvain-la-neuve. Louvain-la-Neuve.

Downey, G 1961. A history of Antioch in Syria. Princeton: Princeton University Press.

Dunbabin, K 2003. The Roman banquet: Images of conviviality. Cambridge: Cambridge University Press.

Dunbabin, M 1999. Mosaics of the Greek and Roman world. Cambridge: Cambridge University Press.

Forbes, C 1954. The Road to Arcady. CJ 50.3:103-109.

Gilhus, I 2006. Animals, gods and humans: Changing attitudes to animals in Greek, Roman and early Christian thought. London: Routledge.

Hachlili, R 2013. Ancient synagogues - Archaeology and art: New discoveries and current research. Leiden: Brill.

Haddad G 1949. Aspects of social life in Antioch in the Hellenistic-Roman period. New York: Hafner.

Hales, S 2003. The Roman house and social identity. Cambridge: Cambridge University Press. 
Howe, T 2008. Pastoral politics: Animals, agriculture and society in ancient Greece. Claremont: Regina Books.

Huskinson, J 2002-2003. Theatre, performance and theatricality in some mosaics pavements from Antioch. BICS 46:131-165.

Jameson, M 1998. Sacrifice and animal husbandry in classical Greece. In Whittaker, C R (ed.). Pastoral economies in Classical Antiquity, 87-119. Cambridge: Cambridge University Press.

Jensen, R M 2000. Understanding early Christian Art. London: Routledge.

Kitzinger, E 1951. Studies on late antique and early Byzantine floor mosaics: I. Mosaics at Nikopolis. DOP 6:81-122.

— 1977. Byzantine art in the making. London: Faber \& Faber.

_ 1995. Stylistic developments in pavement mosaics in the Greek East from the age of Constantine to the age of Justinian. La mosaïque gréco-romaine I Paris: Colloques internationaux de Centre National de la Recherche Scientifique, 341-352. Paris.

Kondoleon, C 2001. Antioch, the lost city. Princeton: Princeton University Press.

— 1995. The triclinium: Dining in an arbor. In Domestic and divine: Roman mosaics in the house of Dionysos, 232-269. Cornell: Cornell University Press.

— 1995. Domestic and divine: Roman mosaics in the house of Dionysos. Cornell: Cornell University Press. 2005. The arts of Antioch. Princeton: Princeton University Press.

Kristensen, W 1971. The worship of animals. In The meaning of religion: Lectures in the phenomenology of religion, 152-163. The Hague: Martinus Nijhoff.

Lassus, J 1936. Les mosaïques d'Antioche. Comptes rendus des séances de l'Académie des Inscriptions et Belles-Lettres, 80e année 1:33-42.

Lavin, D 1963. The hunting mosaics of Antioch and their sources. A study of compositional principles in the development of early mediaeval styles. DOP 17:179-286.

Levi, D 1947. Antioch mosaic pavements. Princeton: Princeton University Press. Lev-Tov, J \& Mcgeough, K 2006. Examining feasting in late bronze age SyroPalestine through ancient texts and bones. In We were what we ate: The archaeology of food and identity. Carbondale: Center for Archaeological Investigations 34:85- 111.

Liebeschuetz, J 1972. Antioch: City and imperial administration in the later Roman Empire. Oxford: Oxford University Press.

Ling, R 1988. Ancient mosaics. Princeton: Princeton University Press.

Lovejoy, A \& Boas, G 1997. Primitivism and related ideas in Antiquity. Baltimore: Johns Hopkins Press. 
Madden, A 2014. Corpus of Byzantine church mosaic pavements from Israel and the Palestinian territories. Leuven: Peeters.

Maguire, H 2012. Nectar and illusion: Nature in Byzantine art and literature. Onassis series in Hellenic culture. Oxford: Oxford University Press.

Martz, A 2002. Maisons d'Antioche à l'époque romaine: Architecture et mobilier archéologique. Nancy: MOM Éditions.

Merrony, M 1998. The reconciliation of Paganism and Christianity in the early Byzantine mosaic pavements of Arabia and Palestine. LA 48:441-482.

Morey, R 1938. The mosaics of Antioch. London: Longmans, Green \& Co.

— 1953. Early Christian art. Princeton: Princeton University Press.

Morvillez, E 2005. L'architecture domestique à Antioche dans l'Antiquité tardive: conservatisme ou modernité? In Becker, L \& Kondoleon, C. The arts of Antioch: Art historical and scientific approaches to Roman mosaics and a catalogue of the Worcester Art Museum Antioch collection, 271-287. Princeton: Princeton University Press.

Murray, C 1981. Rebirth and afterlife. Oxford: B A R International Series.

Neuenfeldt, L 2009. Eros and Erotes in the late antique mosaics of Antioch. Unpublished MA Thesis, Florida.

Petit, P 1955. Libanius et la vie municipale a Antioche. Paris: P Geuthner.

Redding, W 2005. Breaking the mold: A consideration of variation in the evolution of animal domestication. In Vigne, D \& Helmer, D \& Peters, J. The first steps of animal domestication: New archaeological approaches, 41-48. Oxford: OUP.

Rey-Coquais, J 1989. La Syrie, de Pompée à Dioclétien: Histoire politique et administrative. In Dentzer, J \& Orthmann, W. Archéologie et histoire de la Syrie, II, La Syrie de l'époque achéménide à l'avènement de l'Islam. Saarbrücken, 44-75.

Rossiter, J 1989. Roman villas of the Greek east and the villa in Gregory of Nyssa Ep. 20. JRA 2:101-110.

Sandwell, I \& Huskinson, J 2004. Culture and society in later Roman Antioch. Oxford: Oxbow Books.

Sandwell, I 2007. Religious identity in Late Antiquity: Greeks, Jews and Christians in Antioch. Cambridge: Cambridge University Press.

Schiebe, M 2004. Sheep and cattle as ideological markers in Roman poetry. In Frizell, B S 2004. PECUS. Man and animal in Antiquity, 141-145. Rome.

Stillwell, R 1961. Houses of Antioch. DOP 15:47-57.

Tchalenko, G 1953. Villages antiques de la Syrie du Nord: le massif du Bélus a l'époque romaine. Paris: P Geuthner.

Toynbee, J 1973. Animals in Roman life and art. London: Thames and Hudson. 
Vigne, D, Helmer, D \& Peters, J 2005. The first steps of animal domestication: New archaeological approaches. Oxford: OUP.

Whittow, M 1990. Ruling the late Roman and early Byzantine city: A continuous history. $P \& P$ 129:3-29.

Will, E 1989. La Syrie à l'époque hellénistique et romaine: Mille ans de vie intellectuelle et artistique. In Dentzer, J \& Orthmann, W. Archéologie et histoire de la Syrie, II, La Syrie de l'époque achéménide à l'avènement de l'Islam. Saarbrücken, 567-580.

Zeuner, F 1963. A history of domesticated animals. London: Hutchinson. 